\title{
School age children with HIV/AIDS: possible discrimination and attitudes against
}

\author{
CRIANÇAS EM IDADE ESCOLAR COM HIVI AIDS: POSSÍVEL DISCRIMINAÇÃO E \\ ATITUDES CONTRÁRIAS \\ NIÑOS EN EDAD ESCOLAR CON VIH/SIDA: POSIBLE DISCRIMINACIÓN Y \\ ACTITUDES EN CONTRA
}

\section{Donata Kurpas ${ }^{1}$, Bozena Mroczek², Lucyna Sochocka³, Joseph Church ${ }^{4}$}

\begin{abstract}
Survey-based study what purpose was to analyse respondents' opinions about contacts with HIV/AIDS-affected people. It was performed using a paper-pencil method during visits of respondents at primary care centres and on-line through a link to the questionnaire distributed among patients of primary care physicians. The study involved 302 respondents, $80 \%$ of whom were women; the average age was 34.48 years. The majority of respondents did not know anyone with HIV/AIDS (89.6\%). About $83.3 \%$ claimed that they would not decrease contacts with HIV/AIDS-affected people. According to $64.1 \%$ of respondents, children with HIV/AIDS should go to kindergarten/ public or non-public school. We selected a group of respondents, who previously were not but now are inclined to limit such contacts. These respondents can be a potential target group for HIV/AIDS educational programmes. Most respondents think that there is insufficient information about the HIV/AIDS in the mass media.
\end{abstract}

\section{DESCRIPTORS}

Child

HIV

Acquired immunodeficiency syndrome

Health education

Social discrimination

\section{RESUMO}

Inquérito cujo objetivo foi analisar as opiniões de entrevistados sobre contatos com pessoas afetadas por HIV/aids. Um questionário impresso foi aplicado as usuários durante suas visitas a centros de cuidados primários e também disponibilizado online, por meio de um link informado aos pacientes. Envolveu 302 entrevistados, $80 \%$ dos quais eram mulheres, com idade média foi de 34,48 anos. A maioria (89,6\%) não conhecia alguém com HIV/aids e $83,3 \%$ alegaram que não diminuiriam os contatos com pessoas afetadas. De acordo com $64,1 \%$ dos entrevistados, crianças com HIV/aids deveriam frequentar o ensino básico em escola pública ou privada. Foi identificado um grupo de entrevistados que inicialmente não estavam inclinados a limitar esses contatos, mas que haviam mudado de ideia. Esse pode ser um público-alvo em potencial para programas educacionais do HIV/aids. A maioria dos entrevistados considerou que não há informação suficiente sobre HIV/aids nos meios de comunicação.

\section{DESCRITORES \\ Criança \\ HIV}

Síndrome de imunodeficiência adquirida

Educação em saúde

Discriminação social

\section{RESUMEN}

Investigación cuyo objetivo fue analizar las opiniones de los entrevistados sobre contactos con personas afectadas por el VIH/SIDA. Fue aplicado un cuestionario en papel a los usuarios, durante sus visitas a los centros de atención primaria y también vía internet, por medio de un link informativo a los pacientes. Participaron 302 entrevistados, el $80 \%$ de los cuales eran mujeres, la edad promedio fue de 34.48 años. La mayoría no conocía a nadie con $\mathrm{VIH} / \mathrm{SIDA}(89,6 \%)$ y alrededor del $83,3 \%$ afirmó que no disminuirían los contactos con personas afectadas por el VIH/SIDA. De acuerdo con el $64,1 \%$ de los entrevistados, los niños con VIH/SIDA deberían ir a la escuela pública o privada. Fue identificado un grupo de entrevistados, que inicialmente no estaban inclinados a limitar esos contactos, pero luego mudaron de idea. Ellos pueden ser un grupo objetivo potencial para los programas educativos de VIH/SIDA. La mayoría de los entrevistados piensa que no hay suficiente información sobre el VIH/SIDA en los principales medios de comunicación.

\section{DESCRIPTORES \\ Niños \\ VIH}

Síndrome de inmunodeficiencia adquirida Educación en salud Discriminación social

${ }^{1}$ Family Medicine Department, Wroclaw Medical University, Wroclaw, Poland. dkurpas@hotmail.com ${ }^{2}$ Public Health Unit, Faculty of Health Sciences, Pomeranian Medical University, Szczecin, Poland. ${ }^{3}$ Nursing Department, Public Higher Medical Professional School, Opole, Poland. ${ }^{4}$ Board of Supervisors, Roanoke County, Virginia, USA.

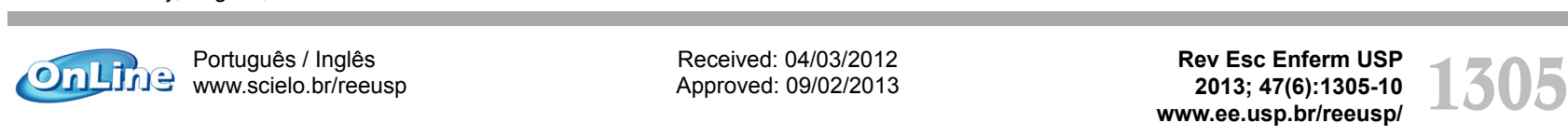




\section{INTRODUCTION}

According to the estimates from UNAIDS (United Nations Programme on HIV/AIDS), approximately 68 million people in the world are infected with HIV. At present, there are about 34 million HIV carriers. Nearly $40 \%$ of people with HIV in the world are between 15 and 24 years old ${ }^{(1-2)}$. Every six seconds someone gets infected with HIV, every nine seconds a person dies from AIDS-related reasons, and every 14 seconds a child is orphaned. Every day about seven thousand people become infected, nearly $10 \%$ of whom are children ${ }^{(2)}$. In 1985, HIV tests were introduced in Poland. Since that time until 31 December 2012, HIV-infection has been diagnosed in 16,314 Polish citizens, 2,848 Aids cases were recorded, and 1,185 of the infected people died ${ }^{(3)}$.

In $90 \%$ of HIV-infected children, the disease progresses slowly with clinical symptoms occurring during the first months of life. These symptoms recede under the influence of therapy and a child may show no other signs of the disease for many years. Probably about $80 \%$ of such children will be in good condition up to the age of eight years, and if treated properly, they will reach their mature years with a chance to function well(4).

The Kaiser Family Foundation commissioned a survey to determine societal attitudes towards school-based HIV/AIDS education and prevention, needle exchange programs, and other HIV/AIDS-related issues. The survey also examined how much Americans know about HIV disease and how they feel about AIDS. The survey found widespread support for AIDS education in schools, and two-thirds of those surveyed favour giving clean needles to injection drug users. Eight in ten parents with children under the age of 21 said they were concerned about their children contracting HIV. Respondents ranked HIV as the nation's number one health concern, and the vast majority of those surveyed knew how HIV was transmitted ${ }^{(5)}$.

Discrimination towards children affected by HIV/ AIDS exists among students and their parents. HIV/AIDS knowledge education helps to improve students and parents' caring and supporting attitudes towards children affected by HIV/AIDS ${ }^{(6)}$. Provide national representative data of 7093 Portuguese adolescents, randomly chosen from students attending 8th and 10th grade of high school. Results showed there was a decrease in positive attitudes regarding people with HIV/AIDS between 2002 and $2006^{(7)}$.

Discrimination against adult carriers of HIV/AIDS is a widely discussed problem in Poland; however there are no reports available about adults' attitudes about contacts between their school-age children and their HIV/AIDS-affected peers ${ }^{(1-2,4)}$.

The purpose of this study was to analyse respondents' opinions about contacts with people infected with HIV or suffering from AIDS as the topic is little explored. The authors were particularly interested in the opinions about potential contacts between respondents' children and those with HIV/AIDS.

\section{METHOD}

This was a cross-sectional, anonymous, self-administered survey in Polish primary care patients from ten primary care centres in Lower Silesia and Opole Province (southern Poland). The study participants were Polish adults randomly chosen from those visiting their primary care physicians for various reasons from 1 January 2009 to 30 April 2010.

Data was collected through a self-administered questionnaire. The information about the same but on-line questionnaire was sent to randomly chosen Polish patients of the primary care centres (PCC). The limited number of respondents (302) results from voluntary participation in the study.

The questionnaire in Polish consisted of 15 questions concerning respondents' gender, age, and place of living, contacts with HIV/AIDS carriers, and the suggested place of education for HIV/AIDS-affected children. Respondents were also asked about their attitudes towards contacts between their children and those with HIV/AIDS, changes in their feelings about contacts with HIV/AIDS carriers over the last few years, and opinions about information on HIV/ AIDS available in mass media.

\section{Statistical analysis}

The variable distribution was assessed using the Shapiro-Wilk test. The null hypothesis about normal distribution of the variable was verified for a significance level equal to 0.05 . The majority of the variables did not have normal distribution. Since the variable distribution was different than normal, Spearman's rank correlation coefficient, Pearson's Chi-squared test and Fisher's exact test were used to assess the power and direction of correlations between the variables. All analyses were carried out using $R$ language ver. 2.10.1 for Mac OS X Cocoa GUI.

\section{RESULTS}

The study involved 302 Polish respondents (the mean age was $34.48 \pm 10.17$ years, median 33 ), including 225 (74.5\%) who completed the questionnaire at the primary 
care centres (the mean age $34.92 \pm 9.53$, median 35 ) and $77(25.5 \%)$ who completed the questionnaire on-line (the mean age $33.20 \pm 11.80$, median 30 ). The age differences between these two groups were statistically significant $(p=$ 0.025 ). Women made up $80 \%$ of all participants in the study (240). Considering sex - no statistically significant differences were found between those completing the questionnaire on-line and in PCC ( $p=0.921)$.

The majority of respondents live in towns with a population of more than 100 thousand $(40.1 \%, 111), 34.3 \%$ (95) from towns with the population of less than 100 thousand, and $25.6 \%$ (71) from the country. Considering the places of residence - statistically significant differences $(p<0.001)$ were found between those completing the questionnaire on-line (majority - 64.9\%, 50 came from towns with the population of more than 100 thousand) and in PCC (majority $-40.0 \%, 80$ came from towns with the population of less than 100 thousand).

As a rule, respondents did not know people with HIV/AIDS: $89.6 \%$ (268) vs. $10.4 \%$ (31), p <0.001. At the same time, the vast majority of respondents declared that they would not decrease contacts with HIV/AIDS carriers from their closest circle: $83.3 \%(250)$ vs. $16.7 \%$ (50), $p<0.001$. Answers to this question correlated with the age of respondents $\left(r_{s}=-0.187, p=0.012\right)$ and the method and place that the questionnaire was completed $\left(r_{s}=0.158, p=0.007\right)$. Limits on contacts with HIV/AIDS carriers were usually declared by respondents older than 60 years and completing the questionnaire at PCC, whereas respondents younger than 20 and completing the questionnaire on-line usually demonstrated quite opposite attitudes.

According to $64.1 \%$ (193) of respondents, children with HIV/AIDS should attend kindergarten/public or non-public schools. These answers were mostly given by respondents coming from towns with the population of more than 100 thousand $\left(r_{s}=-0.044, p=0.013\right)$ and those completing the questionnaire on-line $\left(r_{s}=-0.259, p<0.001\right)$. The replies of $17.6 \%$ (53) of respondents indicate that children with HIV/AIDS should go to integrated kindergarten/schools. Such answers were mostly given by respondents who came from towns with the population of more than 100 thousand $\left(r_{s}=-0.044, p=0.013\right)$ and those completing the questionnaire in PCC $\left(r_{s}=-0.259, p<0.001\right)$. According to $18.3 \%$ (55) of respondents, children with HIV/AIDS should have proposed individual teaching. Answers were mostly given by respondents who came from towns with the population of less than 100 thousand $\left(r_{s}=-0.044\right.$, $p=0.013)$ and those completing the questionnaire in PCC $\left(r_{s}=-0.259, p<0.001\right)$.

About $75.8 \%$ (226) of respondents (vs. 24.2\%, 72, p $<0.001$ ) stated that children with HIV/AIDS could go to a swimming pool with their healthy peers - such opinions were more often expressed by respondents who completed the questionnaire on-line $\left(r_{s}=-0.154, p=0.008\right)$. Some
$79.8 \%$ (241) (vs. 20.2\%, 61, p <0.001) had similar attitudes towards sports competition, and also they were usually respondents who completed the questionnaire on-line $\left(r_{s}=-0.143, p=0.013\right)$.

Statistically significantly more respondents - $69.8 \%$ (208) (vs. 30.2\%, 90, p <0.001) would allow their children to spend free time with their HIV/AIDS-affected peers. Such opinions were statistically significantly more often expressed by residents of towns with the population of more than 100 thousand $(p=0.043)$ and those who completed the questionnaire on-line $\left(r_{s}=-0.2, p=0.0005\right)$. About $74.6 \%$ (223) of respondents (vs. 25.4\%, 76) claimed that they should be informed that a child with HIV/ AIDS went to a kindergarten/school (such answers were mostly given by those completing the questionnaire at PCC, $r_{s}=0.130, p=0.033$ ). At the same time, $81.7 \%$ (245) (vs. $18.3 \%, 55, p<0.001$ ) said that they would not mind if their children attended school where a teacher was a HIV/AIDS carrier. Such answers were provided more often by people between 20 and 40 years of age $(p=0.026)$ and those completing the questionnaire on-line $\left(r_{s}=-0.180\right.$, $\mathrm{p}=0.001$ ).

The respondents were asked if their opinions about contacts between their family members or themselves and HIV/AIDS carriers had changed over the last few years. They claimed that: their opinions had not changed $(76.7 \%, 221)$, they were but are no longer inclined to limit such contacts $(16.0 \%, 46$ - such answers were statistically significantly more often given by women, $p=0.002$ ), they had not been but they became inclined to decrease these contacts $(7.3 \%, 21$ - such answers were more often given by men, $\mathrm{p}=0.002$ ).

Opinions of respondents about information on HIV/AIDS available in mass media are shown in Table 1. Differences between answers provided on-line and at the primary care centres are shown in Table 2.

Table 1 - Opinions about information on HIV/AIDS available in mass media.

\begin{tabular}{lcc}
\hline $\begin{array}{l}\text { Information on AIDS and HIV-infection available in mass media } \\
\text { (press, radio, TV, internet) is* }\end{array}$ & $\mathbf{\%}$ & $\mathbf{N}$ \\
\hline Answers & 46.8 & 141 \\
\hline Insufficient & 42.9 & 129 \\
Intelligible & 28.2 & 85 \\
Easily accessible & 25.2 & 76 \\
Sufficient & 17.3 & 52 \\
Hardly accessible & 8.3 & 11 \\
Unintelligible &
\end{tabular}

* Participants could choose more than one answer 
Table 2 - Differences between answers provided online and at PCC.

\begin{tabular}{|c|c|c|c|}
\hline Answers & $\begin{array}{c}\text { Respondent } \\
\text { PCC } \\
\%(\mathrm{~N}), \mathrm{N}=\mathbf{2 2 5} \\
\end{array}$ & $\begin{array}{c}\text { Respondent } \\
\text { on-line } \\
\%(\mathrm{~N}), \mathrm{N}=77\end{array}$ & $\mathbf{p}^{*}$ \\
\hline I would limit contacts with HIV/AIDS carriers & $20.0(45)$ & $6.5(5)$ & 0.0100 \\
\hline Children with HIV/AIDS should be taught individually & $23.1(52)$ & $3.9(3)$ & 0.0003 \\
\hline Children with HIV/AIDS should not swim in a pool with other children & $27.6(62)$ & $13.0(10)$ & 0.0149 \\
\hline Children with HIV/AIDS should not take part in sports competition with healthy children & $23.6(53)$ & $10.4(8)$ & 0.0204 \\
\hline I would not let my child spend free time with a child having HIV/AIDS & $35.1(79)$ & $14.3(11)$ & 0.0009 \\
\hline I would not let my child go to school where a teacher is a HIV/AIDS carrier & $22.2(50)$ & $6.5(5)$ & 0.0035 \\
\hline
\end{tabular}

* Differences were verified by Chi-squared test (all answers were statistically significant, $p<0.05$ ).

\section{DISCUSSION}

The majority of respondents completed the questionnaire at the PCC. The vast majority of those surveyed did not know anybody with HIV/AIDS. At the same time they declared that they would not limit contacts with HIV/AIDS-affected people (they were usually people younger than 20 years and those who completed the questionnaire on-line, and residents of towns with the population of more than 100 thousand).

The literature on this subject is limited and we did not find similar studies among Polish parents. A study conducted similar among the elementary and middle school students ( $\mathrm{N}=732$ ) and their parents in Northern Thailand ${ }^{(8)}$. The study ${ }^{(8)}$ stated that awareness rates were $77.56 \%(95 \%$ Cl: $63.08 \%$ - 92.05\%) and 81.76\% (95\% Cl: $72.33 \%$ - 91.20\%), respectively. Questions with the lowest proportion of positive attitudes included separating the children affected by HIV/AIDS and not studying with those children in the same class. Gender $(b=-1.15, p=0.016)$ and knowledge of students $(b=1.26, p<0.001)$, as well as attitudes of parents $(b=0.40$, $p<0.001$ ) were associated with the students' attitudes, while parents' knowledge $(b=0.93, p<0.001)$ was associated with parents' attitudes.

The results found started a prevention programme which included information on HIV transmission routes ${ }^{(8)}$. The programme was conducted in three of the study schools. The same questionnaire and focus groups were repeated and the findings showed that children's attitudes had become more supportive. These findings suggest that HIV prevention education delivered through primary schools can be an effective way to help foster a more supportive and inclusive environment and reduce the stigma and discrimination that decrease educational access and attainment for HIV-affected school children ${ }^{(8)}$.

In our study, the majority of Polish respondents said that children with HIV/AIDS should go to kindergarten/public or non-public schools (this attitude was shared mainly by residents of towns with the population of over 100 thousand and those who completed the questionnaire on-line). Unfortunately, $18.3 \%$ thought that children with HIV/AIDS should be taught individually (this opinion was usually expressed by residents of towns with the population of less than 100 thousand and completing the questionnaire at PCC).

According to Polish respondents who completed the questionnaire on-line, children with HIV/AIDS can go to a swimming pool with healthy peers and take part in sports competition. Fewer respondents would let their children spend free time with their HIV/AIDS-affected peers (residents of towns with the population of more than 100 thousand and those completing the questionnaire on-line were more likely to agree). Respondents claimed that they should be informed that a child with HIV/AIDS attended the kindergarten/school (this opinion was more common in the questionnaires completed at PCC).

Similar results were found in the studies ${ }^{(9)}$ : American parents desire more information about the presence of people with AIDS in schools than is permissible by law and that a significant minority of parents objected to allowing HIV-infected students in schools. It was found that more accurate parental knowledge (among American parents) of AIDS and knowing a person with AIDS were associated with greater willingness to allow their children to interact with people with AIDS and with greater acceptance of allowing HIV-infected children to attend regular classes. Support was also found for links between parents' and children's attitudes towards people with AIDS. The studies ${ }^{(9)}$ confirm implications for educating parents about AIDS transmission and inclusion of parents in the implementation of AIDS educational programs.

It is typical that our surveyed (Polish parents) would not object to their children going to school where a teacher with HIV/AIDS is employed (in most cases they were individuals between 20 and 40 years of age, potentially having no children or having schoolchildren, and completing the questionnaire on-line). During the last few years, the majority of respondents did not change their opinions about contacts between their family members or themselves and HIV/AIDS carriers. Unfortunately, 21 have changed their opinions and are now inclined to cut down on such contacts (they are mostly men).

In the study estimating the knowledge about HIV and AIDS of high school students in Iran was found that $44.3 \%$ of students had little knowledge, $36.9 \%$ moderate knowledge 
and only $18.8 \%$ had the highest level of knowledge $\mathrm{e}^{(10)}$. The results also indicated that $15.4 \%$ of student has positive attitudes and $14.9 \%$ - negative. Moreover, results suggested that loyalty to Islamic religious beliefs have an important role in attitude towards this disease. The majority of the study gender, mother's occupation and the use of some mass media such as books and newspapers were other main contributors to the students' attitudes. Furthermore, this study showed that parent education, father's occupation and the use of books and the internet are the most important variables affecting the participants' knowledge. Age, gender, parents' education, religious beliefs, use of some mass media such as TV, the internet, newspapers, satellite and books affect emotion. Finally, there is a relationship between religious beliefs, gender and major of study, the use of satellite, television, radio and books with tendency to action ${ }^{(10)}$. Some of these correlations were also confirmed by our study in Poland.

The factors that contribute to HIV stigma and discrimination include fear of transmission, fear of suffering and death, and the burden of caring for people living with HIV/ AIDS. The family, having access to antiretroviral therapy and other resources, and self-protective behaviours of people living with HIV/AIDS, helped to protect against HIV stigma and discrimination. Variation in the availability of health and socioeconomic resources designed to mitigate the impact of HIV/AIDS helps explain differences in HIV stigma and discrimination across the settings. Increasing access to treatment and care resources may function to lower HIV stigma, however, providing services is not enough.

According to literature ${ }^{(11-12)}$ there is a need for effective strategies to reduce HIV stigma as treatment and care resources are scaled up in the settings that are most heavily impacted by the HIV epidemic. The children with better AIDS knowledge had less personal stigma towards people living with HIV/AIDS ${ }^{(12)}$. The findings in our study and in the study ${ }^{(13)}$ suggest the need of appropriate education strategies to provide AIDS knowledge to children's parents, particularly in communities of high HIV prevalence.

In the studies ${ }^{(14)}$ among 2,392 middle-school students and 1,627 their parents living in high-risk communities in the Midwest the comparison of knowledge and attitudes with respect to AIDS-related issues was made. At the time of the seventh-grade pre-test, parents knew significantly more about AIDS than their children. At the eighth-grade post-test, students who participated in the education programme knew either more than or at least as much as their parents in several subject areas, while among those not exposed to the programme, parents still knew more than their children in most areas.

Similar to results from studies ${ }^{(8-10)}$, this intervention had a positive impact on students' attitudes towards people with AIDS and on their degree of comfort about discussing with their parents such issues as drug use and sexuality ${ }^{(14)}$. Also, studies of other authors confirmed that programmes which promote widespread HIV testing and discussion of HIV/AIDS, as well as education may reduce HIV/AIDS-related stigma and discrimination ${ }^{(15-18)}$. Unfortunately, the majority of participants in our study thought that information regarding HIV/AIDS in mass media was insufficient. The Polish parents did not take part in any educational programme about HIV and/or AIDS.

\section{CONCLUSION}

The majority of respondents claimed that they would not decrease contacts with HIV/AIDS-affected people-such attitudes were more common among younger respondents and those coming from cities. Respondents who were younger and completed the questionnaire on-line more commonly declared that they would have no problem with their children going to school where a teacher was HIV/AIDS carrier. These respondents were also more tolerant towards co-existence of healthy and HIV/AIDS-affected children in peer groups, which referred both to sports activities and spending free time.

The majority of respondents had not changed their opinions about contacts between their family members or themselves and HIV/AIDS affected people over the last few years. However, we selected a group of respondents (mostly men) who previously were not, but became inclined to limit such contacts. These respondents can be a potential target group for HIV/AIDS educational programmes. Most respondents stated that information on HIV/AIDS in mass media was insufficient.

Limitations of our study have to be mentioned: respondents were not asked about their education, nor their children's education. In the future, it could be beneficial to measure current HIV/AIDS knowledge demonstrated by children and their parents, and to assess HIV/AIDS education programmes offered by schools. The limited number in the study group can be attributed to the reluctance to talk, even anonymously, about attitudes regarding HIV/AIDS-affected people (especially children).

\section{REFERENCES}

1. Głazewska J. HIV and AIDS in Poland [Internet]. National Center for AIDS [cited 2013 Aug 25]. Available from: http://www.narkomania.org.pl/czytelnia/122,HIV-i-AIDSw-Polsce
2. Joint United Nations Programme on HIV/AIDS (UNAIDS). Update 2013. How Africa turned AIDS around [Internet]. [cited 2013 Aug 25]. Available from: http://www.unaids. org/en/media/unaids/contentassets/documents/ unaidspublication/2013/20130521_Update_Africa.pdf 
3. National Institute for Public Health. AIDS in Poland [Internet]. [cited 2013 Aug 25]. Available from: http://www.pzh.gov.pl/ oldpage/epimeld/hiv_aids/2012.htm\#12

4. Halota W, Juszczyk J. HIV/AIDS. Poznan: Termedia; 2006.

5. Survey finds broad support for AIDS education in schools. AIDS Policy Law. 1996; 11(8):1,10.

6. Shan X, Yang T. Attitude of elementary and middle school students and their parents toward children affected by HIV/ AIDS and its determinants. Zhong Nan Da Xue Xue Bao Yi Xue Ban. 2011;36(5):448-52.

7. Reis M, Ramiro L, Matos MG, Diniz JA, Simões C. Information and attitudes about HIV/AIDS in Portuguese adolescents: state of art and changes in a four year period. Psicothema. 2011;23(2):260-6.

8. Ishikawa N, Pridmore P, Carr-Hill R, Chaimuangdee K. The attitudes of primary schoolchildren in Northern Thailand towards their peers who are affected by HIV and AIDS. AIDS Care. 2011;23(2):237-44.

9. Osborne ML, Kistner JA, Helgemo B. Parental knowledge and attitudes toward children with AIDS: influences on educational policies and children's attitudes. J Pediatr Psychol. 1995;20(1):79-90.

10. Movahed M, Shoaa S. On attitude towards HIV/AIDS among Iranian students (case study: high school students in Shiraz City). Pak J Biol Sci. 2010;13(6):271-8.
11. Maman S, Abler L, Parker L, Lane T, Chirowodza A, Ntogwisangu $J$, et al. A comparison of HIV stigma and discrimination in five international sites: the influence of care and treatment resources in high prevalence settings. Soc Sci Med. 2009;68(12):2271-8.

12. Herek GM, Capitanio JP, Widaman KF. HIV-related stigma and knowledge in the United States: prevalence and trends, 19911999. Am J Public Health. 2002;92(3):371-7.

13. Zhao Q, Li X, Zhao G, Zhao J, Fang X, Lin X, et al. AIDS knowledge and HIV stigma among children affected by HIV/AIDS in rural China. AIDS Educ Prev. 2011;23(4):341-50.

14. Levy SR, Weeks K, Handler A, Perhats C, Franck JA, Hedeker D, et al. A longitudinal comparison of the AIDS: related attitudes and knowledge of parents and their children. Fam Plann Perspect. 1995;27(1):4-10,17.

15. Verby C, Herold ES. Parents and AIDS education. AIDS Educ Prev. 1992;4(3):187-96

16. Greeff $M$, Phetlhu R. The meaning and effect of HIV/AIDS stigma for people living with AIDS and nurses involved in their care in the North West Province, South Africa. Curationis. 2007;30(2):12-23.

17. Genberg BL, Hlavka Z, Konda KA, Maman S, Chariyalertsak S, Chingono A, et al. A comparison of HIV/AIDS-related stigma in four countries: negative attitudes and perceived acts of discrimination towards people living with HIV/AIDS. Soc Sci Med. 2009;68(12):2279-87.

18. Plummer ML, Wight D, Obasi Al, Changalucha J, Hayes RJ, Ross DA. AIDS education programmes hit some targets: improving youth HIV prevention by sharing resources and better addressing community norms and concurrency. AIDS. 2011;25(8):1139-41. 